\title{
Content Analyses of Scientific Articles Published in Sport Mont Journal Year 2007
}

\author{
Boris Banjevic ${ }^{1}$ \\ 'Army of Montenegro, Airforce Military of Montenegro, Podgorica, Montenegro
}

\begin{abstract}
Sport Mont is a scientific journal which has been existing since 2003 and it has published a great number of works of renowned scientists in the field of sport sciences and medicine. The journal has been indexed in more international database, it is released three times a year, and the published works are mostly presented on the scientific conference of the Montenegrin Sport Academy. Sport Mont, in addition to the original scientific works, publishes reviews, editorials, short reports, as well as the calls and awards for works in the field of sport sciences and medicine. This work deals with the analysis of the content of published articles in the journal Sport Mont in 2007. They have been sorted according to the scientific fields they belong to, and through discussion, a short overview of the obtained results has been given. This way makes possible an easier search of the mentioned articles for the authors who express their interest for them.
\end{abstract}

Key words: Sport science, Sport Mont Journal, Medicine

\section{Uvod}

Crnogorska sportska akademija je osnovana 2003. godine, kada je pokrenut i naučni časopis Sport Mont. Ovaj naučni časopis ima dugogodišnju tradiciju, koja baštini visoke standarde i norme stručnog, naučnog, moralnog i etičkog digniteta. Prepoznatljiv u okruženju, regionalno i mnogo šire, Sport Mont predstavlja značajnu naučnu bazu u kojoj se mogu naći radovi eminentnih stručnjaka iz oblasti sportskih nauka, medicine i fizičkog vaspitanja. Zapravo, on pokriva veliki broj naučnih disciplina čiji su izvori saznanja od posebnog značaja za razumijevanje brojnih kinezioloških fenomena. To se prije svega odnosi na biomehaniku, fiziologiju, kineziterapiju, fizikalnu terapiju, traumatologiju sportskih povreda, trenažnu tehnologiju, antropologiju sporta, pedagogiju-sociologiju i psihologiju sporta, sportski menadžment i sve ostale aspekte vježbanja, zdravlja i sporta. Časopis je indeksiran u 23 međunarodne naučne baze podataka, od kojih je Scopus najprestižnija baza. Izlazi tri puta godišnje i radovi koji su objavljeni u njemu su većinom predstavljeni na naučnoj konferenciji Crnogorske sportske akademije, koja se tradicionalno održava svake godine.

Pored originalnih naučnih radova, Sport Mont objavljuje pregledne radove, uvodnike, kratke izvještaje, nagrade radova u oblasti sportskih nauka i medicine i funkcioniše kao otvoreni forum za diskusiju o značajnim aktuelnim pitanjima. Ovaj časopis obezbjeđuje transparentnost i dostupnost naučnim radnicima širom svjetskih meridijana. Stoga, on pruža online otvoren pristup, brzo objavljivanje, mišljenje stručnjaka i istraživača, post publikacijske alate za pokazivanje kvaliteta i učinka, zajednicu zasnovanu na zajedničkom jeziku članaka i svjetsku medijsku pokrivenost.

Sport Mont je, doživljavajući brojne transformacije, prelazio evolutivni put napretka, čije ga tekovine danas postavljaju u ravan najpriznatijih časopisa istog stvaralačkog područja u cijelom svijetu. Egzistiranje časopisa u današnjem obliku je rezultat stručnog, posvećenog i pregalačkog rada glavnih urednika časopisa i članova uredničkog odbora, koji su uspjeli na ovaj način značajno doprinijeti razvoju kineziološke nauke na našim prostorima. Glavni i odgovorni urednici časopisa su prof. dr Duško Bjelica sa Univerziteta Crne Gore i prof. dr Zoran Milošević sa Univerziteta u Novom Sadu. Izvršni urednik je mr Jovica Gardašević sa Univerziteta Crne Gore. Uređivački odbor čini 15 profesora iz Crne Gore, regiona, Evrope i Sjeverne Amerike.

\section{Correspondence:}

\section{Montenegro}

Sport

\section{B. Banjevic}

Army of Montenegro, Airforce military of Montenegro, Military airport "Knjaz Danilo" Podgorica, Montenegro

E-mail: boris.banjevic@gmail.com 
Do sada su izvršene brojne analize sadržaja iz časopisa Sport Mont, a cilj ovog rada je selektovanje članaka objavljenih 2007. godine, po odgovarajućim naučnim oblastima kojima pripadaju. Na ovaj način će biti omogućen lakši pristup i pretraga onim autorima koji se budu služili radovima objavljenim u pomenutom vremenskom periodu.

\section{Metod rada}

U ovom radu biće korišćena metoda analize sadržaja, koja se efikasno primjenjuje u raznovrsnim područjima ljudskog rada i stvaralaštva. Ona podrazumijeva korišćenje pisanih izvora kao osnovne jedinice izvora informacija. Ovdje su to svi naučni članci objavljeni kroz tri broja (12,13 i 14) časopisa
Sport Mont 2007. godine. Ukupno je objavljeno 119 članaka, koji će biti klasifikovani prema sljedećim naučnim oblastima: biomehanika; korektivna gimnastika; sportska medicina; antropologija sporta; psihologija, sociologija i pedagogija sporta; fiziologija sporta; sportski trening i metodika treninga; istorija sporta i bibliografija; turizam, menadžment i marketing $\mathrm{u}$ sportu.

\section{Rezultati}

Nakon sprovedene kompletne analize sadržaja iz Sport Monta, izvršena je klasifikacija radova u devet oblasti, kako je prikazano u tabeli 1.

Tabela 1. Podjela radova prema naučnim oblastima

\begin{tabular}{lc}
\hline Naučna oblast & Broj radova \\
\hline Biomehanika & 5 \\
Korektivna gimnastika & 5 \\
Sportska medicina & 6 \\
Antropologija sporta & 43 \\
Psihologija, sociologija i pedagogija sporta & 23 \\
Fiziologija sporta & 4 \\
Sportski trening i metodika treninga & 20 \\
Istorija sporta i bibliografija & 3 \\
Turizam, menadžment i marketing u sportu & 10 \\
\hline
\end{tabular}

Biomehanika je naučna disciplina koja svojim sadržajem sjedinjuje mehaniku i anatomiju ispitujući zakone relativnog kretanja i mirovanja čovjeka. Radovi iz ove oblasti su: "Dinamika biomehaničke tehnologije" (Bjelica, 2007), "Biomehanical model of the sprint start" (Čoh, 2007), "Mišićni disbalans fudbalera ustanovljen izokinetičkom dijagnostikom" (Doder i Golik-Perić, 2007), "Biomehanika karvinog zavoja u alpskom skijanju” (Hadžić, 2007) i Biomehanička analiza slobodnog zamaha (Opavsky, 2007).

Korektivna gimnastika predstavlja strukturalni segment kineziterapije i primjenjuje se u prevenciji i korekciji funkcionalnih poremećaja i promjena na lokomotornom aparatu. Iz ove oblasti su objavljeni sljedeći naučni radovi: "Dijagnostika stanja građe stopala kod djece predškolskog uzrasta u ustanovi za predškolsko vaspitanje i obrazovanje "Sokolac" u Sokocu" (Bjeković i Arnaut, 2007), "Prisustvo posturalnih poremećaja kod mlađeg školskog uzrasta u zavisnosti od nivoa informisanosti roditelja o lošem držanju tela" (Bogdanović, 2007), "Uloga nastavnika na formiranje pravilnog držanja tela" (Bogdanović, 2007), "Transverzalna analiza učestalosti lordotičnih poremećaja kod dvanaestogodišnjih dječaka i djevojčica” (Jovović, 2007) i "Prisutnost skoliotičnog lošeg držanja i razlike u morfološkim karakteristikama odbojkašica i rukometašica" (Milenković i Nejić, 2007).

Sportska medicina je naučna disciplina koja se bavi primjenom medicine i nauke u sprječavanju, prepoznavanju, liječenju i rehabilitaciji povreda izazvanih sportom, vježbanjem ili rekreativnim aktivnostima. Ova naučna oblast $\mathrm{u}$ Sport Mont časopisu je bila zastupljena kroz sljedeće radove: "Doping i nedozvoljene metode u sportu" (Bjelica, 2007), "Iznenadne smrti kod sportista” (Đukanović i Ražnatović, 2007), "Fizička aktivnost djece u gradskoj sredini” (M. Joksimović i V. Joksimović, 2007), "Funkcionalno osposobljavanje i fizikalni tretman sportista nakon povrede kolateralnih ligamenata zgloba koljena" (M. Joksimović i V. Joksimović, 2007), "Hijerarhijski pristup dijagnostičkom materijalu B.I.A. parametara” (Obradović i Rajković, 2007) i "Najčešće korišćeni steroidi kod sportista" (Vasić i Jakonić, 2007)

Antropologija je naučna disciplina koja se bavi konstrukcijom antropoloških modela, utvrđivanjem strukture i relacija antropoloških karakteristika, kao i utvrđivanjem relacija u odnosu na odgovarajuće kineziološke fenomene. Zastupljeni radovi iz ove oblasti su sljedeći: "Kanoničke relacije bazično-motoričkih sposobnosti i uspješnosti u nogometnoj igri kod juniora premijer lige" (Bajramović i Mekić, 2007), "Kategorizacija sportskih disciplina prema nivou elementarnih biomotornih dimenzija" (Bjelica, 2007), "Prediktivna vrijednost nekih testova opšte motorike na formiranje ocjene u nastavi fizičkog vaspitanja" (Bulatović, 2007), "Povezanost eksplozivne snage sa vrhunskim rezultatima u karateu" (Doder i Babiak, 2007), "Razlike u morfološkim i motoričkim pokazateljima grupa vrhunskih rvača i boksera" (Drapšin i Drid, 2007), "Razlike u funkcionalnim i motoričkim pokazateljima grupa vrhunskih karatista i džudistkinja" (Drid i Vujkov, 2007), "Uticaj step aerobika na transformaciju antropometrijskih karakteristika i motoričkih sposobnosti studenata" (Đug i Mikić, 2007), "Uticaj motoričkih sposobnosti i konativnih karakteristika na brzinu vođenja lopte i preciznost u košarci" (Hadžić, 2007), "Motoričke sposobnosti dečaka mlađeg školskog uzrasta" (Janković i Stojiljković, 2007), "Neke antropometrijske karakteristike dvanaestogodišnje djece u Nikšiću" (Jovović, 2007), "Uticaj različitih programa nastave fizičkog vaspitanja na antropometrijske karakteristike ispitanika" (Kljajević, 2007), "Razlike motoričkih sposobnosti studenata kriminalističko-policijske akademije iz Beograda i dobro treniranih osoba" (Koropanovski i Janković, 2007), "Neke morfološke karakteristike fudbalera" (Lilić, 2007), "Doprinos fakultativnih aktivnosti rukometa u transformaciji motoričkog statusa učenica prvog razreda srednje škole" (Marković i Višnjić, 2007), "Selekcija u rukometu" (Marušić, 2007), "Regresiona analiza testova za 
procjenu bazično-motoričkih i situaciono-motoričkih sposobnosti nogometaša-juniora premijer lige u prostoru konativnih karakteristika" (Mekić i Bajramović, 2007), "Uticaj motoričkih sposobnosti na uspješnost izvođenja specifičnih motoričkih testova u rvanju” (Mikić i Ahmeti, 2007), "Prediktivna vrijednost nekih testova motoričkih sposobnosti za predviđanje uspjeha u brzini prelaska preko konopca” (Mujanović i Nožinović, 2007), "Struktura morfoloških karakteristika bodibildera” (Mutavdžić i Milenović, 2007), "Relacije između morfoloških karakteristika i preciznosti dodavanja lopte kod košarkaša pionirskog uzrasta" (Nikolić, 2007), "Relacije između motoričkih sposobnosti i preciznosti dodavanja lopte kod košarkaša pionirskog uzrasta" (Nikolić, 2007), "Povezanost morfoloških karakteristika studenata sa uspjehom u izvođenju narodnih igara” (Nožinović-Mujanović, 2007), "Da li su dečaci mlađeg školskog uzrasta gojazni?” (Obradović i Srdić, 2007), "Da li su devojčice mlađeg školskog uzrasta gojazne?" (Obradović i Srdić, 2007), "Odnos morfoloških dimenzija mehanizma energetske regulacije” (Pavlović, 2007), "Razlike u povezanosti motoričkih sposobnosti sa uspješnošću u realizaciji programskih sadržaja sportske gimnastike u odnosu na uzrast ispitanika" (Petković, 2007), "Povezanost motoričkih sposobnosti učenika IV razreda srednje škole sa uspješnošću u realizaciji programskih sadržaja sportske gimnastike" (Petković, 2007), "Komparativna analiza kraniofacijalne antropometrije učenica i učenika V razreda osnovnih škola u Nišu" (Purenović, 2007), "Indeks telesne mase i dijametri glave učenika V razreda osnovnih škola u Nišu" (Purenović, 2007), "Morfofunkcionalni status taekwon-do sportista reprezentacije Srbije” (Rajković i Obradović, 2007), "Razlike u morfološkim karakteristikama sportista u sportskim igrama" (Rakočević, 2007), "Uticaj repetitivne snage na razvoj specifične koordinacije i uspješnost savladavanje tehnike fudbalera-početnika" (Rakočević, 2007), "Relacije bazično-motoričkih sposobnosti i specifične preciznosti fudbalera uzrasta 10-12 godina" (Smajić i Molnar, 2007), "Neka od atletskih kretanja kao osnova za motoričku sposobnost vrhunskih fudbalera" (Stefanović i Milenković, 2007), "Istraživanje senzitivnih perioda preciznosti kod učenika osnovne škole" (Stijepić i Nićin, 2007), "Razlike u morfološkom prostoru između učenika sportista i ostalih učenika srednjeg školskog uzrasta" (Stojiljković i Janković, 2007), "Relacije bazično-motoričkih sposobnosti sa situaciono-motoričkim sposobnostima u fudbalu" (Šabotić i Drobnjak, 2007), "Selekcija mladih za sprint”" (Šolaja, 2007), "Razlike između motoričkih sposobnosti studenata kriminalističko-policijske akademije iz Beograda i kategorisanih sportista-karatisti” (Vučković i Koropanovski, 2007), "Uticaj osnovne obuke u gađanju kod policajaca u funkciji pola" (Vučković i Dopsaj, 2007), "Biotipska determinisanost modela mladih rukometaša uzrasta 16-18 godina” (Vujović, 2007), "Morfološke karakteristike učenika prvog, drugog i trećeg razreda osnovne škole" (Zrnzević, 2007) i "Motoričke sposobnosti učenica prvog, drugog i trećeg razreda osnovne škole” (Zrnzević, 2007).

Iz oblasti psihologije, sociologije i pedagogije sporta, koje objašnjavaju brojna stanja psihe spotrista u različitim okolnostima, položaj jedinke u sportskom kolektivu, odnose pojedinca prema grupi ili šire društvenoj zajednici, kao i zakonitosti unutar složenih pedagoških okvira, zastupljeni su sljedeći radovi: "Korektivno-kompenzatorna uloga rekreacije u životu i radu savremenog čovjeka" (Bijelić, 2007), "Metodološko modelno zasnivanje dopunskog profesionalnog usavršavanja profesora fizičkog vaspitanja sa aspekta njihove sociokulturne i pedagoške usmjerenosti” (Bjeković, 2007), "Sport i kultura mira" (Bjelica, 2007), "Povezanost fizičke aktivnosti devojčica i njihovih roditelja sa pozitivnim odnosom devojčica prema fizičkoj aktivnosti" (Čokorilo i Mikalački, 2007), "Povezanost fizičke aktivnosti devojčica i njihovih roditelja sa odnosom roditelja prema fizičkoj aktivnosti” (Čokorilo, N. i Čokorilo, R., 2007), "Od sportskih aktivnosti do sportske delatnosti" (Džeko i Bjelica, 2007), "Short introduction to ethical reasoning in sport” (Hosta, 2007), "Sedeća odbojka kao važno terapijsko sredstvo i značajna sportska aktivnost u obrazovanju i vaspitanju hendikepiranih učenika" (Kabok, 2007), "Razlike učinka između pobjedničkih i poraženih ekipa na Svjetskom nogometnom prvenstvu 2006" (Kapidžić i Mujanović, 2007), "Starosna struktura vrhunskih rvačica" (Kasum i Radović, 2007), "Saznanja o pravilnoj ishrani sportista u Crnoj Gori" (Klarić i Vujačić, 2007), "Odnos sportske aktivnosti i uspeha u učenju” (Lepeš, 2007), "Sportske nauke i strategije unapređenja stila života stanovništva” (Maksimović i Vasić, 2007), "Uslovi i opremljenost osnovnih škola za realizaciju nastave fizičkog vaspitanja, kao i doprinos i uticaj nastavnika u neposrednoj nastavi" (Martinović i Branković, 2007), "Analiza strukture stavova i mišljenja nastavnika razredne nastave prema fizičkom vaspitanju” (E. Međedović i A. Međedović, 2007), "Saradnja nastavnika fizičkog vaspitanja sa organizacijama u fizičkoj kulturi” (E. Međedović i A. Međedović, 2007), "Psihološka i taktička priprema tenisera juniorske kategorije” (Milenković, 2007), "Strah od vode ili umišljeni događaji koji se čine stvarnim" (Milošević, 2007), "Opisno ocjenjivanje u fizičkom vaspitanju” (Milošević, 2007), "Stavovi i interesi radnika Mlina "Muharem Asović” prema sportskoj rekreaciji” (Nikolić, 2007), "Čitanje stručnog sportskog teksta na stranom jeziku” (Pirsl, 2007), “Značaj sporta u evropskim integracijama sa osvrtom na Crnu Goru” (Rašović, 2007) i "Stavovi adolescenata prema nastavi fizičkog vaspitanja" (Višnjić i Marković, 2007).

Fiziologija sporta je integralni dio sportske medicine i bavi se izučavanjem funkcionisanja organskih sistema i organizma u cjelosti prilikom raznovrsnih fizičkih aktivnosti čovjeka. Iz ove oblasti su zastupljeni sljedeći radovi: "Ples kao dopunsko sredstvo u sportu" (Karanov i Protić-Gava, 2007), "Faktori od kojih zavisi zamor kod plivača” (Madić i Okičić, 2007), "Faktorska struktura funkcionalnih sposobnosti bodibildera" (Milenović i Mutavdžić, 2007) i "Intenzifikacija časa fizičkog vaspitanja košarka-vođenje lopte” (Šabotić i Dedeić, 2007).

Sportski trening i metodika treninga kao sastavni dio trenažne tehnologije, omogućavaju transformacione procese pojedinih segmenata antropološkog statusa sportiste i usavršavanje tehničko-taktičkih-elemenata, što u krajnjem vodi ka postizanju vrhunskih sportskih dostignuća. Iz ovog veoma važnog segmenta su prikazani sljedeći radovi: "Efekti koncentrisane nastave plivanja u savladavanju plivačkih tehnika" (Bulatović, 2007), "Struktura tehničko-taktičkih dejstava košarkaških ekipa NBA lige” (Jovanova-Simeva, 2007), "Uticaj različitih modela plivačkog treninga (definisanih u odnosu na anaerobni prag) na promjene varijabli tjelesnog sastava" (Krivokapić, 2007), "Efekti različitih modela plivačkog treninga (definisanih u odnosu na anaerobni prag) na povećanje brzine plivanja" (Krivokapić, 2007), "Razvoj nekih motoričkih sposobnosti studenata nakon desetodnevne nastave smučanja" (Lilić, 2007), "Kondicione pripreme za biciklističke trekking ture" (Martinović i Branković, 2007), "Primijenjena sportska akrobatika u trenažnom procesu rukometa” (Marušić, 2007), 
"Izbor vežbi i varijanti u treningu kružnog napadača" (Mavrić, 2007), "Program elemenata parterne gimnastike za individualni rad sa kružnim napadačem” (Mavrić, 2007), "Uticaj trenažnog procesa na brzinsku sposobnost, agilnost i skočnost odbojkašica" (Nejić, 2007), "Pouzdanost nekih testova za procenu izvođenja tehnike u džudou" (Obadov i Kopas, 2007), "Obuka i usavršavanje tehnike tai otoši” (Obadov, 2007), "Most kao dominantna tehnička struktura u rvanju grčko-rimskim i slobodnim stilom” (Radović i Kasum, 2007), “Tenis u Crnoj Gori sa posebnim osvrtom na metodologiju rada na teniskom zidu" (D. Rašović i I. Rašović, 2007), "Osnovne karakteristike i tehnika veslanja u turističkom kanu čamcu” (Savić, 2007), "Planiranje i programiranje trenažnog procesa kod mladih sprintera u pripremnom periodu" (Stefanović i Mekić, 2007), "Model za povećanje izdržljivosti kandidata za prijemni ispit Fakulteta sporta i fizičkog vaspitanja" (Šolaja, 2007), "Homogenost rezultata u zavisnosti od dionica i tehnika plivanja" (Trivun i Vuković, 2007), "Specifičnost pliometrijskog treninga u karateu” (Vujkov, 2007) i "Metodski pristup učenja osnovnih tehničko-taktičkih elemenata u rukometu” (Vujović, 2007).

U oblasti istorija sporta i bibliografija zastupljena su tri rada u kojima je prikazana zanimljiva hronološka retrospektiva bibliografkih jedinica koje su se odnosile na pojedina sportska zbivanja, objašnjen je način sistematizacije bibliografskih fondova i data su glavna obilježja prikupljanja istorijskih podataka. Radi se o sljedećim radovima: "Bibliografija radova dr Duška Bjelice u Jugoslovenskom sportskom listu "Sport”: 1984/85 godine" (Krivokapić, 2007), "Predmetna klasifikacija u nauci o sportu” (Protić, 2007) i "Heuristika na primeru istraživanja u sportu i fizičkom vaspitanju” (Savić, 2007).

Turizam, menadžment i marketing u sportu, predstavljaju veoma bitne karike u složenom sistemu društvenih odnosa $\mathrm{u}$ sportu. Iz ovih oblasti su sljedeći radovi: "Sport za sve i rekreacija u uslovima tranzicije društva i tržišne ekonomije" (Bijelić, 2007), "Sadašnji opšti uslovi za sport i turizam” (Bjelica, 2007), "Direktni uticaj sponzorstva na razvoj sporta" (Đuranović i Novaković, 2007), "Rijeka Zeta kao potencijal za razvoj sportsko-rekreativnih oblika turizma" (Jovović, 2007), "Ponašanje potrošača u sportu” (Ljubojević i Vetro, 2007), "Organizacija rada ronilačkog centra” (V. Mijajlović i D. Mijajlović, 2007), "Struktura menadžmenta sportske organizacije tranzicionog oblika vlasništva" (Nikolić, 2007), "Finansiranje sporta u međunarodnim takmičenjima" (Stojčinović, 2007), "Sportsko turističke mogućnosti nacionalnog parka i olimpijske planine kao vid organizovanja aktivnosti u prirodi” (Trivun, 2007) i "Modernizacija opreme u sportskim teretanama kao preduslov razvoja body buildinga” (Vukasović, 2007).

\section{Diskusija}

U ovom radu izvršena je klasifikacija naučnih članaka iz časopisa Sport Mont, koji su obljavljeni 2007. godine. Metodom analize sadržaja utvrđeno je da su isti iz sljedećih oblasti: biomehanika (5), korektivna gimnastika (5), sportska medicina (6), antropologija sporta (43), psihologija, sociologija i pedagogija sporta (23), fiziologija sporta (4), sportski trening i metodika treninga (20), istorija sporta i bibliografija (3) i turizam, menadžment i marketing u sportu (10). Najveći broj istraživanja je iz antropologije sporta, što i ne čudi obzirom na veliki opseg ove naučne discipline i sami značaj problematike koju tretira. Naime, ovdje je pažnja bila usmjerena na utvrđivanju raznovrsnih uticaja i relacija između pojedinih segmenata antropološkog statusa, kao i njihov prediktivni aspekt na raznovrsne kineziološke manifestacije. Istraživanja iz ove kompleksne oblasti daju nesumnjiv teorijski i praktični doprinos, rasvjetljavajući brojne nedoumice vezane za kompleksno funkcionisanje "sistema čovjek" u najraznovrsnijim kretnim postavkama. Poslije antropologije sporta, najviše radova je bilo iz oblasti psihologije, pedagogije i sociologije sporta. U ovim radovima je primjetna tendencija objašnjavanja položaja sportiste ili učenika u veoma raznovrsnim i složenim društvenim okolnostima i situacijama koje nameću ispoljavanje njihovih kognitivnih i konativnih modela funkcionisanja. Nesumnjivo, radovi skoncentrisani u ovom segmentu su dali značajan doprinos razumijevanju problematike društvenog života, vaspitanja i psiholoških odrednica savremenog čovjeka. Po svojoj zastupljenosti, slijede radovi koji se tiču procesa trenažne tehnologije. U njima je težište stavljeno na utvrđivanju efekata dejstva raznovrsnih trenažnih tretmana na unaprijeđivanje kondicionih potencijala i usavršavanje tehnike izvođenja kretanja u pojedinim sportovima. Suština značaja rezultata dobijenih ovim istraživanjima je $u$ davanju konkretnih smjernica za usavršavanje djelotvornih trenažnih transformacionih procesa, kako bi došlo do postizanja vrhunskog sportskog postignuća. Ovdje je takođe naglašen i broj radova iz turizma, menadžmenta i marketinga u sportu. Ove teme su dale doprinos shvatanju brojnih dešavanja u sportu i turizmu $u$ kontekstu savremenog poimanja socioekonomskih fenomena. Iako su radovi iz biomehanike, sportske medicine i korektivne gimnastike zastupljeni u znatno manjem broju, oni su obzirom na značaj predmeta proučavanja ipak ostavili značajan trag u ovom izdanju časopisa. Ustanovljeno je da su ovi radovi dali brojne činjenične postavke koje su od posebnog značaja za poimanje raznovrsnih kretnih struktura, unaprijeđivanje posturalnog statusa školske djece i omladine, kao i shvatanje brojnih činilaca koji dovode do nastanka sportskih povreda. Sve ovo ima nesumnjiv teorijski i praktičan značaj za nastavu fizičkog vaspitanja i sportsku djelatnost. Sport Mont iz 2007. godine su dopunila i tri istraživanja vezana za istoriju sporta i bibliografiju, što je u konačnom dalo predstavu o njemu kao o jednom izuzetno uspješnom izdanju, koje je zajedno sa ostalim izdanjima trasiralo put ka samom vrhu najčitanijih sportskih časopisa u regionu i šire.

\section{Acknowledgements}

There are no acknowledgements.

\section{Conflict of Interest}

The authors declare that there are no conflicts of interest.

Received: 1 March 2019 | Accepted: 12 March 2019 | Published: 19 April 2019

References

Bajramović, Š., \& Mekić, M. (2007). Kanoničke relacije bazično-motoričkih sposobnosti i uspješnosti u nogometnoj igri kod juniora premijer lige. Sport Mont, 5(12-13-14), 323-30.

Bijelić, B. (2007). Sport za sve i rekreacija u uslovima tranzicije društva i tržišne ekonomije. Sport Mont, 5(12-13-14), 151-7.

Bijelić, B. (2007). Korektivno-kompezatorna uloga rekreacije u životu i radu savremenog čovjeka. Sport Mont, 5(12-13-14), 303-9.

Bjeković, G. (2007). Metodološko modelno zasnivanje dopunskog profesionalnog usavršavanja profesora fizičkog vaspitanja sa aspekta njihove sociokulturne i pedagoške usmjerenosti. Sport Mont, 5(12-13-14), $225-$ 34.

Bjeković, G., \& Arnaut, Đ. (2007). Dijagnostika stanja građe stopala kod djece predškolskog uzrasta u ustanovi za predškolsko vaspitanje i obrazovanje "Sokolac" u Sokocu. Sport Mont, 5(12-13-14), 374-80.

Bjelica, D. (2007). Sport i kultura mira. Sport Mont, 5(12-13-14), 4-9.

Bjelica, D. (2007). Doping i nedozvoljene metode u sportu. Sport Mont, 5(1213-14), 27-34. 
Bjelica, D. (2007). Dinamika biomehaničke tehnologije. Sport Mont, 5(12-1314), 532-8.

Bjelica, D. (2007). Kategorizacija sportskih disciplina prema nivou elementarnih biomotornih dimenzija. Sport Mont, 5(12-13-14), 814-9.

Bjelica, S., \& Džeko, Š. (2007). Sadašnji opšti uslovi za sport i turizam. Sport Mont, 5(12-13-14), 527-31.

Bogdanović, Z. (2007). Prisustvo posturalnih poremećaja kod mlađeg školskog uzrasta u zavisnosti od nivoa informisanosti roditelja o lošem držanju tela. Sport Mont, 5(12-13-14), 609-15.

Bogdanović, Z. (2007). Uloga nastavnika na formiranju pravilnog držanja tela. Sport Mont, 5(12-13-14), 694-702.

Bulatović, D. (2007). Prediktivna vrijednost nekih testova opšte motorike na formiranje ocjene u nastavi fizičkog vaspitanja. Sport Mont, 5(12-13-14), 276-84.

Bulatović, D. (2007). Efekti koncentrisane nastave plivanja u savladavanju plivačkih tehnika. Sport Mont, 5(12-13-14), 499-505.

Čoh, M. (2007). Biomechanical model of the sprint start. Sport Mont, 5(1213-14), 19-26.

Čokorilo, N., \& Mikalački, M. (2007). Povezanost fizičke aktivnosti devojčica i njihovih roditelja sa pozitivnim odnosom devojčica prema fizičkoj aktivnosti. Sport Mont, 5(12-13-14), 134-8.

Čokorilo, N., \& Čokorilo, R. (2007). Povezanost fizičke aktivnosti devojčica i njihovih roditelja sa odnosom roditelja prema fizičkoj aktivnosti. Sport Mont, 5(12-13-14), 445-50.

Doder, D., \& Babiak, J. (2007). Povezanost eksplozivne snage sa vrhunskim rezultatima u karateu. Sport Mont, 5(12-13-14), 784-91.

Doder, D., \& Golik-Perić, D. (2007). Mišićni disbalansi fudbalera ustanovljen izokinetičkom dijagnostikom. Sport Mont, 5(12-13-14), 115-20.

Drapšin, M., \& Drid, P. (2007). Razlike u morfološkim i motoričkim pokazateljima grupa vrhunskih rvača i boksera. Sport Mont, 5(12-13-14), 732-7.

Drid, P., \& Vujkov, S. (2007). Razlike u funkcionalnim i motoričkim pokazateljima grupa vrhunskih karatiskinja i džudiskinja. Sport Mont, 5(12-13-14) 47-52.

Džeko, Š., \& Bjelica, S. (2007). Od sportskih aktivnosti do sportske delatnosti. Sport Mont, 5(12-13-14), 292-6.

Đug, M., \& Mikić, B. (2007). Uticaj step aerobika na transformaciju antropometrijskih karakteristika i motoričkih sposobnosti studenata. Sport Mont, 5(12-13-14), 129-33.

Đukanović, N., \& Ražnatović, A. (2007). Iznenadne smrti kod sportista. Sport Mont, 5(12-13-14), 411-5.

Đuranović, D., \& Novaković, S. (2007). Direktni uticaj sponzorstva na razvoj sporta. Sport Mont, 5(12-13-14), 654-62.

Hadžić, R. (2007). Uticaj motoričkih sposobnosti i konativnih karakteristika na brzinu vođenja lopte i preciznost u košarci. Sport Mont, 5(12-13-14), 180-5.

Hadžić, R. (2007). Biomehanika karvinog zavoja u alpskom skijanju. Sport Mont, 5(12-13-14), 360-5.

Hosta, M. (2007). Short introduction to ethical reasoning in sport. Sport Mont, 5(12-13-14), 345-50.

Janković, I., \& Stojiljković, S. (2007). Motoričke sposobnosti dečaka mlađeg školskog uzrasta. Sport Mont, 5(12-13-14), 551-6.

Joksimović, M., \& Joksimović, V. (2007). Fizička aktivnost djece u gradskoj sredini. Sport Mont, 5(12-13-14), 273-5.

Joksimović, V., \& Joksimović, M. (2007). Funkcionalno osposobljavanje fizikalni tretman sportista nakon povrede kolateralnih ligamenata zgloba koljena. Sport Mont, 5(12-13-14), 649-53.

Jovanova-Simeva, V. (2007). Struktura tehničko-taktičkih dejstava košarkaških ekipa NBA lige. Sport Mont, 5(12-13-14), 285-91.

Jovović, O. (2007). Rijeka Zeta kao potencijal za razvoj sportsko-rekreativnih oblika turizma. Sport Mont, 5(12-13-14), 827-40.

Jovović, V. (2007). Neke antropometrijske karakteristike dvanaestogodišnje djece u Nikšiću. Sport Mont, 5(12-13-14), 80-6.

Jovović, V. (2007). Transverzalna analiza učestalosti lordotičnih poremećaja kod dvanaestogodišnjih dječaka i djevojčica. Sport Mont, 5(12-13-14), 381-6.

Kabok, I. (2007). Sedeća odbojka kao važno terapijsko sredstvo i značajna sportska aktivnost u obrazovanju i vaspitanju hendikepiranih učenika. Sport Mont, 5(12-13-14), 249-53.

Karanov, B., \& Protić-Gava, B. (2007). Ples kao dopunsko sredstvo u sportu. Sport Mont, 5(12-13-14), 588-93.

Kapidžić, A., \& Mujanović, E. (2007). Razlike učinka između pobjedničkih i poraženih ekipa na Svjetskom nogometnom prvenstvu 2006. Sport Mont 5(12-13-14), 297-302.

Kasum, G., \& Radović, M. (2007). Starosna struktura vrhunskih rvačica. Sport Mont, 5(12-13-14), 351-9.

Klarić, D., \& Vujačić, V. (2007). Saznanja o pravilnoj ishrani sportista u Crnoj Gori. Sport Mont, 5(12-13-14), 261-6.

Kljajević, V. (2007). Uticaj različitih programa nastave fizičkog vaspitanja na antropometrijske karakteristike ispitanika. Sport Mont, 5(12-13-14), 38795.

Koropanovski, N., \& Janković, R. (2007). Razlike motoričkih sposobnost studenata kriminalističko-policijske akademije iz Beograda i dobro treniranih osoba. Sport Mont, 5(12-13-14), 738-43.

Krivokapić, D. (2007). Uticaj različitih modela plivačkog treninga (definisanih u odnosu na anaerobni prag) na promjene varijabli tjelesnog sastava. Sport Mont, 5(12-13-14), 158-66.

Krivokapić, D. (2007). Efekti različitih modela plivačkog treninga (definisanih u odnosu na anaerobni prag) na provećanje brzine plivanja. Sport Mont, 5(12-13-14), 310-8

Krivokapić, P. (2007). Bibliografija radova dr Duška Bjelice u Jugoslovenskom sportskom listu „Sport": 1984/85. godine. Sport Mont, 5(12-13-14), 84169.

Lepeš, J. (2007). Odnos sportske aktivnosti i uspeha u učenju. Sport Mont 5(12-13-14), 63-71.

Lilić, Lj. (2007). Neke morfološke karakteristike fudbalera. Sport Mont, 5(1213-14), 632-7.

Lilić, Lj. (2007). Razvoj nekih motoričkih sposobnosti kod studenata nakon desetodnevne nastave smučanja. Sport Mont, 5(12-13-14), 721-4.

Ljubojević, Č., \& Vetro, L. (2007). Ponašanje potrošača u sportu. Sport Mont, 5(12-13-14), 459-67.

Madić, D., \& Okičić, T. (2007). Faktori od kojih zavisi zamor kod plivača. Sport Mont, 5(12-13-14), 602-8.

Maksimović, N., \& Vasić, G. (2007). Sportske nauke i strategije unapređenja stila života stanovništva. Sport Mont, 5(12-13-14), 95-101.

Marković, Ž., \& Višnjić, D. (2007). Doprinos fakultativnih aktivnosti-rukometa u transformaciji motoričkog statusa učenica prvog razreda srednje škole. Sport Mont, 5(12-13-14), 53-62.

Martinović, D., \& Branković, D. (2007). Kondicione pripreme za biciklističke treking ture. Sport Mont, 5(12-13-14), 337-44.

Martinović, D., \& Branković, D. (2007). Uslovi i opremljenost osnovnih škola za realizaciju nastave fizičkog vaspitanja, kao i doprinos i uticaj nastavnika u neposrednoj nastavi. Sport Mont, 5(12-13-14), 616-22.

Marušić, R. (2007). Selekcija u rukometu. Sport Mont, 5(12-13-14), 805-13.

Marušić, R. (2007). Primijenjena sportska akrobatika u trenažnom procesu rukometa. Sport Mont, 5(12-13-14), 820-6.

Mavrić, F. (2007). Program elemenata parterne gimnastike za individualni rad sa kružnim napadačem. Sport Mont, 5(12-13-14), 780-3.

Mavrić, F. (2007). Izbor vežbi i varijanti u treningu kružnog napadača. Sport Mont, 5(12-13-14), 797-804.

Međedović, E., \& Međedović, A. (2007). Analiza strukture stavova i mišljenja nastavnika razredne nastave prema fizičkom vaspitanju. Sport Mont, 5(12-13-14), 451-8.

Međedović, E., \& Međedović, A. (2007). Saradnja nastavnika fizičkog vaspitanja sa organizacijama u fizičkoj kulturi. Sport Mont, 5(12-13-14), 66876.

Mekić, M., \& Bajramović, Š. (2007). Regresiona analiza testova za procjenu bazično-motoričkih i situaciono-motoričkih sposobnosti nogometaša-juniora Premijer lige u prostoru konativnih karakteristika. Sport Mont, 5(12-13-14), 35-46.

Mijajlović, V., \& Mijajlović, D. (2007). Organizacija rada ronilačkog centra. Sport Mont, 5(12-13-14), 725-31.

Mikić, B., \& Ahmeti, V. (2007). Uticaj motoričkih sposobnosti na uspješnost izvođenja specifičnih motoričkih testova u rvanju. Sport Mont, 5(12-1314), 396-402

Milenković, S. (2007). Psihološka i taktička priprema tenisera juniorske kategorije. Sport Mont, 5(12-13-14), 594-601.

Milenković, S., \& Nejić, D. (2007). Prisutnost skoliotično lošeg držanja i razlike u morfološkim karakteristikama odbojkašica i rukometašica. Sport Mont, 5(12-13-14), 638-48.

Milenović, P., \& Mutavdžić, V. (2007). Faktorska struktura funkcionalnih sposobnosti bodibildera. Sport Mont, 5(12-13-14), 267-72.

Milošević, D. (2007). Strah od vode ili umišljeni događaji koji se čine stvarnim. Sport Mont, 5(12-13-14), 110-5.

Milošević, D. (2007). Opisno ocjenjivanje u fizičkom vaspitanju. Sport Mont 5(12-13-14), 519-26.

Mujanović, E., \& Nožinović, F. (2007). Prediktivna vrijednost nekih testova motoričkih sposobnosti za predviđanje uspjeha u brzini prelaska preko konopca. Sport Mont, 5(12-13-14), 139-44.

Mutavdžić, V., \& Milenović, P. (2007). Struktura morfoloških karakteristika bodibildera. Sport Mont, 5(12-13-14), 544-50.

Nejić, D. (2007). Uticaj trenažnog procesa na brzinsku sposobnost, agilnost i skočnost odbojkašica. Sport Mont, 5(12-13-14), 681-8.

Nikolić, B. (2007). Relacije između motoričkih sposobnosti i preciznosti dodavanja lopte kod košarkaša pionirskog uzrasta. Sport Mont, 5(12-13-14), 199-203.

Nikolić, B. (2007). Relacije između morfoloških karakteristika i preciznosti 
dodavanja lopte kod košarkaša pionirskog uzrasta. Sport Mont, 5(12-1314), 484-8.

Nikolić, I. (2007). Struktura menadžmenta sportske organizacije tranzicionog oblika vlasništva. Sport Mont, 5(12-13-14), 319-22.

Nikolić, M. (2007). Stavovi i interesi radnika Mlina "Muharem Asović“ prema sportskoj rekreaciji. Sport Mont, 5(12-13-14), 429-34.

Nožinović, A., \& Nožinović, Z. (2007). Povezanost morfoloških karakteristika studenata sa uspjehom u izvođenju narodnih igara. Sport Mont, 5(1213-14), 145-50.

Obadov, S., \& Kopas, J. (2007). Pouzdanost nekih testova za procenu tehnike u džudou. Sport Mont, 5(12-13-14), 744-9.

Obadov, S. (2007). Obuka i usavršavanje tehnike tai otoši. Sport Mont, 5(1213-14), 755-61.

Obradović, B., \& Srdić, B. (2007). Da li su dečaci mlađeg školskog uzrasta gojazni? Sport Mont, 5(12-13-14), 574-8.

Obradović, B., \& Srdić, B. (2007). Da li su devojčice mlađeg školskog uzrasta gojazne? Sport Mont, 5(12-13-14), 762-6.

Obradović, Z., \& Rajković, Ž. (2007). Hijerarhijski pristup dijagnostičkom materijalu B.I.A. parametara. Sport Mont, 5(12-13-14), 715-20.

Opavsky, P. (2007). Biomehanička analiza slobodnog zamaha. Sport Mont 5(12-13-14), 10-8.

Pavlović, R. (2007). Odnos morfoloških dimenzija mehanizma energetske regulacije. Sport Mont, 5(12-13-14), 513-8.

Petković, J. (2007). Povezanost motoričkih sposobnosti učenika IV razreda srednje škole sa uspješnošću u realizaciji programskih sadržaja sportske gimnastike. Sport Mont, 5(12-13-14), 254-60.

Petković, J. (2007). Razlike u povezanosti motoričkih sposobnosti sa uspješnošću u realizaciji programskih sadržaja sportske gimnastike u odnosu na uzrast ispitanika. Sport Mont, 5(12-13-14), 489-98.

Pirsl, D. (2007). Čitanje stručnog-sportskog teksta na stranom jeziku. Sport Mont, 5(12-13-14), 468-76.

Protić, P. (2007). Predmetna klasifikacija u nauci o sportu. Sport Mont, 5(1213-14), 566-73.

Purenović, T. (2007). Komparativna analiza kraniofacijalne antropometrije učenica i učenika V razreda osnovnih škola u Nišu. Sport Mont, 5(12-13 14), 623-31.

Purenović, T. (2007). Indeks telesne mase i dijametar glave učenika V razreda osnovnih škola u Nišu. Sport Mont, 5(12-13-14), 703-14.

Radović, M. \& Kasum, G. (2007). Most kao dominantna tehnička struktura u rvanju grčko-rimskim i slobodnim stilom. Sport Mont, 5(12-13-14), 2438.

Rajković, Ž., \& Obradović, Z. (2007). Morfofunkcionalni status taekwon-do sportista reprezentacije Srbije. Sport Mont, 5(12-13-14), 750-4.

Rakočević, T. (2007). Uticaj repetitivne snage na razvoj specifične koordinacije i uspješnost savladavanja tehnike fudbalera-početnika. Sport Mont 5(12-13-14), 192-8.

Rakočević, T. (2007). Razlike u morfološkim karakteristikama sportista u sportskim igrama. Sport Mont, 5(12-13-14), 477-83.

Rašović, D., \& Rašović, I. (2007). Tenis u Crnoj Gori s posebnim osvrtom na metodologiju rada na teniskom zidu. Sport Mont, 5(12-13-14), 366-73.

Rašović, I. (2007). Značaj sporta u evropskim integracijama sa osvrtom na Crnu Goru. Sport Mont, 5(12-13-14), 677-80.

Savić, Z. (2007). Heuristika na primeru istraživanja u sportu i fizičkom vaspi- tanju. Sport Mont, 5(12-13-14), 579-87.

Savić, Z. (2007). Osnovne karakteristike i tehnika veslanja u turističkom kanu čamcu. Sport Mont, 5(12-13-14), 767-74.

Smajić, M., \& Molnar, S. (2007). Relacije bazično motoričkih sposobnosti specifične preciznosti fudbalera uzrasta 10-12 godina. Sport Mont, 5(1213-14), 87-94.

Stefanović, R., \& Mekić, B. (2007). Planiranje i programiranje trenažnog procesa kod mladih sprintera u pripremnom periodu. Sport Mont, 5(12-1314), 173-9.

Stefanović, R., \& Milenković, V. (2007). Neka od atletskih kretanja kao osnova za motoričku sposobnost vrhunskih fudbalera. Sport Mont, 5(12-13-14), 539-43.

Stijepić, R., \& Nićin, Đ. (2007). Istraživanje senzitivnih perioda preciznosti kod učenika osnovne škole. Sport Mont, 5(12-13-14), 204-15.

Stoiljković, S., \& Janković, I. (2007). Razlike u morfološkom prostoru između ičenika sportista i ostalih učenika srednjeg školskog uzrasta. Sport Mont, 5(12-13-14), 792-6.

Stojčinović, M. (2007). Finansiranje sporta u međunarodnim takmičenjima. Sport Mont, 5(12-13-14), 662-7.

Šabotić, B., \& Drobnjak, D. (2007). Relacije bazično-motoričkih sposobnost sa situaciono-motoričkim sposobnostima u fudbalu. Sport Mont, 5(1213-14), 167-72

Šabotić, B., \& Dedeić, N. (2007). Intenzifikacija časa fizičkog vaspitanja košarka-vođenje lopte. Sport Mont, 5(12-13-14), 331-6.

Šolaja, M. (2007). Model za povećanje izdržljivosti kandidata za prijemni ispit Fakulteta sporta i fizičkog vaspitanja. Sport Mont, 5(12-13-14), 689-93.

Šolaja, M. (2007). Selekcija mladih za sprint. Sport Mont, 5(12-13-14), 775-9.

Trivun, M. (2007). Sportsko turističke mogućnosti nacionalnog parka olimpijske planine kao vid organizovanja aktivnosti u prirodi. Sport Mont, 5(12-13-14), 422-8.

Trivun, M., \& Vuković, S. (2007). Homogenost rezultata u zavisnosti od dionica i tehnika plivanja. Sport Mont, 5(12-13-14), 216-24.

Vasić, G., \& Jakonić, D. (2007). Najčešće korišćeni steroidi kod sportista. Sport Mont, 5(12-13-14), 102-9.

Višnjić, D., \& Marković, Ž. (2007). Stavovi adolescenata prema nastavi fizičkog vaspitanja. Sport Mont, 5(12-13-14), 435-44.

Vučković, G., \& Dopsaj, M. (2007). Uticaj osnovne obuke u gađanju kod policajaca u funkciji pola. Sport Mont, 5(12-13-14), 557-65.

Vučković, G., \& Koropanovski, N. (2007). Razlike između motoričkih sposobnosti studenata kriminalističko-policijske akademije iz Beograda i kategorisanih sportista-karatisti. Sport Mont, 5(12-13-14), 235-42.

Vujkov, S. (2007). Specifičnost pliometrijskog treninga u karateu. Sport Mont 5(12-13-14), 72-9.

Vujović, D. (2007). Biotipska determinisanost modela mladih rukometaša uzrasta 16-18 godina. Sport Mont, 5(12-13-14), 186-91.

Vujović, D. (2007). Metodski pristup učenja osnovnih tehničko-taktičkih elemenata u rukometu. Sport Mont, 5(12-13-14), 506-12.

Vukasović, D. (2007). Modernizacija opreme u sportskim teretanama kao preduslov razvoja body buildinga. Sport Mont, 5(12-13-14), 416-21.

Zrnzević, N. (2007). Motoričke sposobnosti učenica prvog, drugog i trećeg razreda osnovne škole. Sport Mont, 5(12-13-14), 121-8.

Zrnzević, N. (2007). Morfološke karakteristike učenika prvog, drugog i trećeg razreda osnovne škole. Sport Mont, 5(12-13-14), 403-10. 